\title{
FIQIH CINTA
}

(Cara Bijak Hukum Islam Menyemai Cinta dan Membina Keluarga)

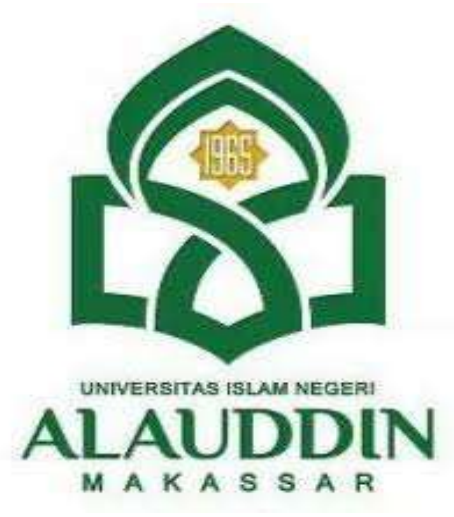

MAKALAH

Disampaikan Pada Seminar Kelas Mata Kuliah Hukum Islam Kontemporer (S3) UIN Alauddin Makassar

Semester Genap Tahun 2018

Oleh:

Z A K I R A H

NIM.80100317007

Email: zakirahira17@gmail.com

Dosen Pemandu:

Prof. Dr. Hj. Andi Rasdiyanah

Prof. Dr. H. Kasyim Salenda, SH., M.Th.I

PROGRAM PASCA SARJANA (S3)

UNIVERSITAS ISLAM NEGERI ALAUDDIN

MAKASSAR

2020 


\section{BAB I \\ PENDAHULUAN}

\section{A. Latar Belakang Masalah}

Dalam proses penciptaan manusia sampai dengan keberadaannya di muka bumi ini, dimana manusia adalah makhluk Allah SWT yang paling sempurna dalam penciptaannya, dibandingkan dengan makhluk lainnya. Karena salah satu diantara kelebihan manusia adalah memiliki kecenderungan tertarik pada lawan jenisnya. Ketertarikan terhadap lawan jenis atau biasa disebut degan racsa cinta dan kasih sayang yang merupakan persoalan krusial bagi manusia sehingga seharusnya memiliki kedudukan penting di dalam ajaran agama Islam. Namun anehnya, justru sangat sedikit kalangan ulama Muslim yang membahas persoalan ini dengan memberikan saran pendapat yang beragam pula. Akibatnya, ilmu tentang cinta dan kasih sayang jarang sekali dibahas secara komprehensif. Padahal cinta adalah anugerah Allah SWT. yang bernuansa lembut dan indah.

Dalam pandangan Islam, fithrah manusia adalah suatu potensi keagamaan yang terbawa sejak lahir dan potensi tersebut dapat bertumbuh dan berkembang. ${ }^{1}$ Makna kata cinta adalah fitrah manusia yang ditanamkan oleh Allah sejak diciptakan, agar keturunan Nabi Adam tetap lestari dan tercipta cinta kasih di antara manusia sehingga hidup penuh dengan kerahmatan dan kedamaian. Ketika seseorang telah jatuh cinta kepada lawan jenis adalah hal manusiawi dalam arti kata normal dan sangat dianjurkan, Islam tidak melarang seseorang untuk jatuh cinta, mencintai dan dicintai. Hanya saja, Islam menunjukkan

\footnotetext{
${ }^{1}$ Arsyam, M., \& Kusnadi Umar, Z. Z. MANUSIA SEBAGAI PENDIDIK PERPEKTIF ISLAM DAN BARAT.
} 
wadah yang suci melalui pernikahan untuk menyalurkan hasrat cinta sepasang manusia agar dapat bercinta dengan bebas sekaligus mendapat ridha dan diberkahi. Allah Swt. berfirman :

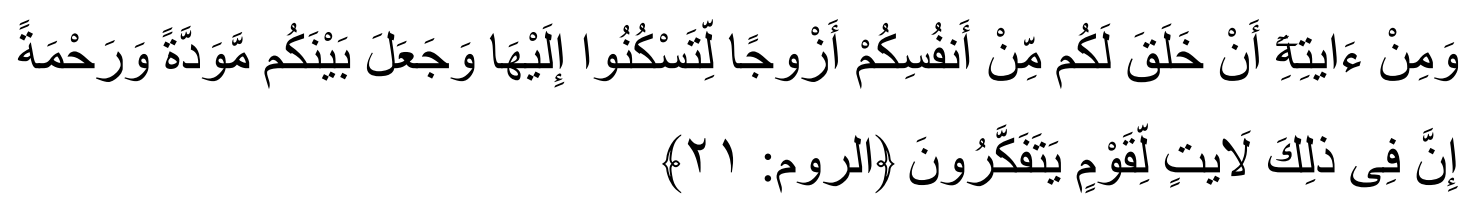

Terjemahnya :

Dan di antara tanda-tanda ke-kuasaan-Nya ialah dia mencip-takan untukmu isteri-isteri dari jenismu sendiri, supaya kamu cenderung dan merasa tente-ram kepadanya, dan dijadi-kanNya diantaramu rasa kasih dan sayang. Sesungguhnya pada yang demikian itu benar-benar terdapat tanda-tanda bagi kaum yang berfikir (QS. 30/Ar-Rum: 21$)^{2}$

Pada ayat di atas dijelaskan bahwa hati yang bersatu karena Allah (setelah menikah), maka Allah akan menyemai rasa cinta dan kasih sayang kepada pria atau wanita yang menjadi pasangan hidupnya. Sebelum menikah rasa cinta kepadanya akan biasa-biasa saja, tidak akan sekuat dan setulus ketika setelah menikah. Ikatan hati akan semakin kuat setelah menikah, karena akan tumbuh rasa lebih saling memiliki, saling menjaga dan dorongan untuk rela berkorban demi pasangan hidupnya.

Cinta yang tidak dikemas oleh pernikahan, akan terkesan hanya melampiaskan hawa nafsu belaka, maka tidak ada bedanya dengan hewan yang hanya bersenang-senang dengan lawan jenisnya tanpa ada ikatan yang sah. Ironisnya di akhir zaman sekarang ini, banyak yang lebih memilih menyalurkan hasrat cintanya pada wadah yang haram yang bertentangan dengan syariat Islam dan dimurkai oleh Allah swt. yaitu pacaran.

\footnotetext{
${ }^{2}$ Departemen Agama R.I. Al Quran dan Terjemahnya, (Bandung: CV Diponegoro, 2013), h. 572.
} 
Hidup berumah tangga kadangkala rumit dan kompleks. Hal tersebut bisa saja timbul karena fondasi bangunan rumah tangga itu sendiri tidak kokoh atau salah satu komponennya ada yang berusaha untuk menghancurkan. Pernikahan dalam konsepsi Islam merupakan perbuatan yang mengandung hukum syar'i yang bervariasi tergantung dari keadaannya. Pernikahan merupakan titik tolak hakiki bagi pembangunan peradaban dan pemikiran umat. Peningkatan kualitas masyarakat tidak bisa dilakukan dengan mengesampingkan pembangunan kualitas keluarga dan kebahagiaan jiwa juga tergantung pada kemapanan keluarga.

\section{B. Rumusan Masalah}

Berdasarkan dari uraian di atas maka akan menjadi fokus pembahasan dalam makalah ini adalah sebagai berikut :

1. Bagaimana tentang konsep cinta dalam Islam?

2. Bagaimana kiat Islam menyemai cinta dan membina keluarga?

3. Bagaimana Implementasi cint menurut hukum Islam? 


\section{BAB II}

\section{PEMBAHASAN}

\section{A. Konsep Cinta dalam Islam}

Syeikh Athiyyah Shaqr menyatakan, cinta dalam kehidupan manusia adalah ketergantungan hati yang dirasakan oleh orang yang cinta dengan rasa lezat dan tenang. Cinta adalah santapan rohani dan pemuas bagi naluri manusia serta penyegar bagi perasaan. ${ }^{3}$ Menurut Muhammad Thohir, cinta merupakan sikap hidup yang toleran, jujur, adil, penuh cinta dan kasih sayang terharlap sesama merupakan refleksi kecer-dasan spiritual. $^{4}$

Sedangkan kata cinta dalam al-Quran disebut Hubb (mahabbah) dan Wudda (mawaddah), keduanya memiliki arti yang sama yaitu menyukai, senang, menya-yangi. ${ }^{5}$ Firman Allah Swt.:

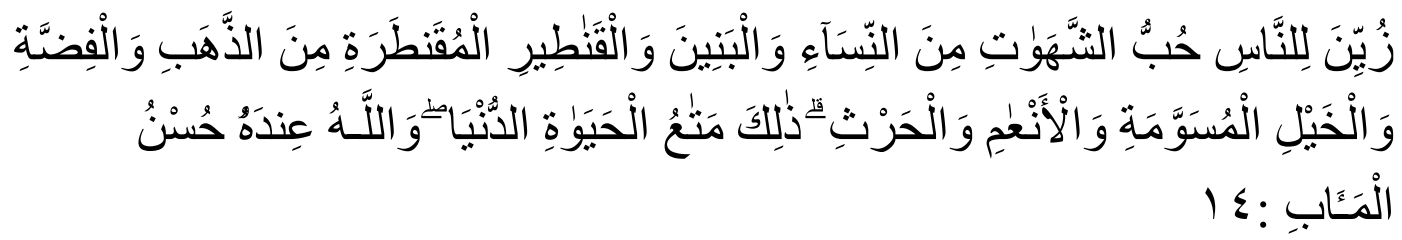

Terjemahnya :

Dijadikan indah pada (pandengan) manusia kecintaan kepada apa-apa yang diingini, yaitu: wanita-wanita, anak-anak, harta yang banyak dari jenis emas, perak, kuda pilihan, binatang binatang ternak dan sawah ladang. Itulah kesenangan hidup di dunia, dan di sisi Allah-lah tempat kembali yang baik (surga) (QS. 3/Ali Imran: 14). ${ }^{6}$

${ }^{3}$ Syeikh Athiyyah Shaqr, Fatawa li al-Syabab, Diterjemah oleh M.Wahib Aziz dengan Judul Fatwa Kontemporer Seputar Dunia Remaja (Cet.I; Jakarta: Amzah, 2003), h. 12.

4 Muhammad Thohir, Pengantar Memasuki Paradigma Baru Kehidupan yang Lebih Bermartabat, Lebih Sehat den Lebih Bahagia (Cet. I; Jakarta: Lentera Hati, 2006), h. 156.

5 www.tentangcinta.com/artikel-cinta/definisi-cinta/dan www.mya85.ultiply.com/eviews/tem 27 diakses tanggal 10 MEI 2017.

${ }^{6}$ Kementerian Agama RI, Al-Qur'an dan Terjemahnya, h. 64. 
Jadi Wudda (kasih sayang) diberikan Allah sebagai hadiah atas keimanan, amal sholeh manusia, hal ini dipertegas lagi dalam firman Allah :

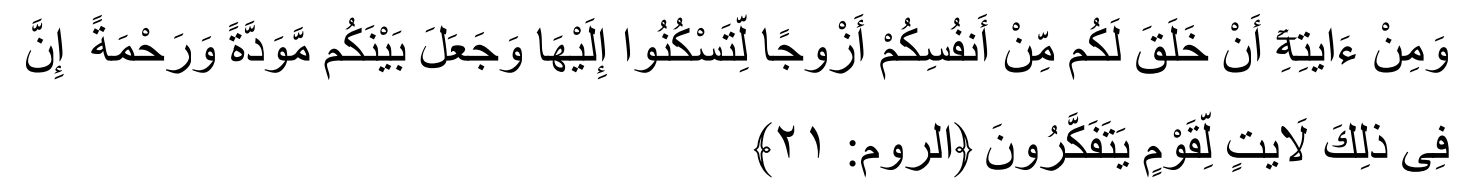

Terjemahnya :

Dan diantara tanda-tanda kekuasaan-Nya ialah ia men-ciptakan untukmu dari jenismu sendiri, supaya kamu cen-derung merasa tentram kepa-danya, dan dijadikan-Nya diantaramu rasa kasih dan sayang (QS. 30/Ar Rum: 21). ${ }^{7}$

Dalam ayat ini pun Allah menggambarkan "cenderung dan tentram" yang dapat diraih dengan pernikahan oleh masing-masing pasangan akan diberi hadiah (ja'ala) kasih sayang dan rahmat.

Dalam praktiknya, istilah pacaran dengan tunangan sering dirangkai menjadi satu. Muda-mudi yang pacaran, kalau ada kesesuaian lahir-batin, dilanjutkan dengan tunangan. Sebaliknya, mereka yang bertunangan biasanya diikuti dengan pacaran. Pacaran dimaksudkan sebagai proses mengenal pribadi masing-masing pasangan, sedangkan tunangan itu adalah perjanjian untuk mengikat pernikahan, yang seringkali ditandai dengan tukar cincin atau perkenalan antara kedua keluarga.

Namun yang menjadi persoalan dewasa ini terkadang pacaran itu dimaknai dengan bermesraan, berpelukan, berciuman, dan bahkan sampai pada hubungan intim. Hal ini jelas bertentangan dengan nilai adat, budaya, kemanusiaan yang beradab, dan tuntutan Islam. Semua perkara yang dapat mendekatkan seseorang ke arah perzinaan, atau seks pranikah itu dilarang secara tegas.

\footnotetext{
${ }^{7}$ Kementerian Agama RI, Al-Qur'an dan Terjemahnya, h. 572.
} 


\section{B. Kiat Islam dalam Menyemai Cinta}

Islam memiliki kiat dan etika dalam menyemai cinta dan membina keluarga. Adapun tahapan umumnya dapat diuraikan sebagai berikut :

\section{Proses Perkenalan}

Langkah awal dalam menjalin cinta menuju perkawinan adalah hendaknya masing-masing pasangan melakukan perkenala untuk mengetahui latar belakang sosial, budaya, pendidikan, dan kondisi keluarganya, tanpa melakukan kiat-kiat yang tidak patut menurut kaca mata adat, budaya, dan agama, maka kiat itu bukan saja tidak bertentangan dengan Islam, bahkan justru itulah yang dianjurkan pada tiap pasangan, agar mereka berdua mengenal satu lama lain, sehingga diharapkan dengan saling kena itu, keluarga yang hendak dibangun dapat tegak berdiri, tak mudah goyah, tahan lama, dan harmonis. Allag Swt. berfirman :

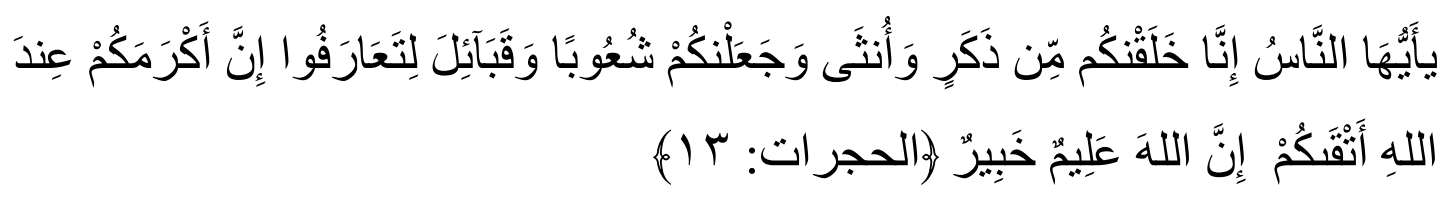

Terjemahnya :

Hai manusia, sesungguhnya Kami menciptakan kamu dari seorang laki-laki dan seorang perempuan dan menjadikan kamu berbangsa-bangsa dan bersuku-suku supaya kamu sating mengenal. Sesungguhnya orang yang paling mulia diantara kamu di sisi Allah ialah orang yang paling bertakwa diantara kamu. Sesungguhnya Allah Mafia Mengetahui lagi Maha Mengenal (QS. 49/Al Hujurat: 13). ${ }^{8}$

Setelah bertemu dan tertarik satu sama lain, dianjurkan untuk dapat mengenal kepribadian, latar belakang sosial, budaya, pendidikan, keluarga, maupun agama kedua belah pihak. Dengan tetap menjaga martabat senonoh, bila di antara

\footnotetext{
${ }^{8}$ Kementerian Agama RI, Al-Qur'an dan Terjemahnya, h. 745.
} 
mereka berdua terdapat kecocokan, maka bisa diteruskan dengan saling mengenal kondisi keluarga masing-masing, missalnya dengan jalan bersilaturrahmi ke orang tua keduanya. Dengan cara seperti ini, kedua keluarga pasangan yang sudah saling kenal tadi itu pun dapat melihat seperti apa orang yang nantinya akan ber-gabung menjadi keluarga besar mereka. Sebab, ikatan pernikahan dalam pandengan Islam itu bukanlah antara dua orang, seorang pria dengan seorang wanita saja, melainkan antara dua keluarga. ${ }^{9}$

Bila seorang pria telah menerima seorang wanita sebagai istrinya, maka iapun hendaknya menerima keluarga si perempuan layaknya keluarganya sendiri, dan memperlakuan mertuanya layaknya orang tuanya sendiri. Bukan sebaliknya, menerima si wanita, tapi menolak keluarganya. Kalau hal itu yang terjadi, berarti pernikahannya tersebut tidak mendapat restu dari salah satu pihak keluarga. Bila yang demikian itu dilakukannya karena alasan demi membela cinta, maka ketahuilah bahwa bangunan keluarga yang hendak ditegakkan tersebut tidak memiliki tiang yang kokoh, artinya kebahagiaan yang hendak digapai melalui mahligai keluarga tadi tidaklah utuh. Hal itu disebabkan manusia sebagai makhluk sosial membutuhkan kehadiran orang lain, dan orang lain yang terdekat itu tidak lain adalah arang tua atau keluarga.

Nabi saw. memberikan tips bagi seseorang yang hendak memilih pasangannya, yaitu mendahulukan pertimbangan keberagamaan dari pada motif kekayaan, keturunan, maupun kecantikan atau ketampanan. Sebab, agama merupakan modal yang penting untuk membangun keluarga sakinah, mawaddah dan rahmah, serta akan

\footnotetext{
${ }^{9}$ Ali Hasan Umar, Kejahatan seks dan Kehamilan di Luar Nikah dalam Pandangan Islam (cet. I; Semarag: Panca Agung, 2003), h. 79.
} 
menghasilkan putra-putri yang shalih atau shalihah. Diriwayatkan dari al-Dailami bahwasanya Nabi saw. bersabda:

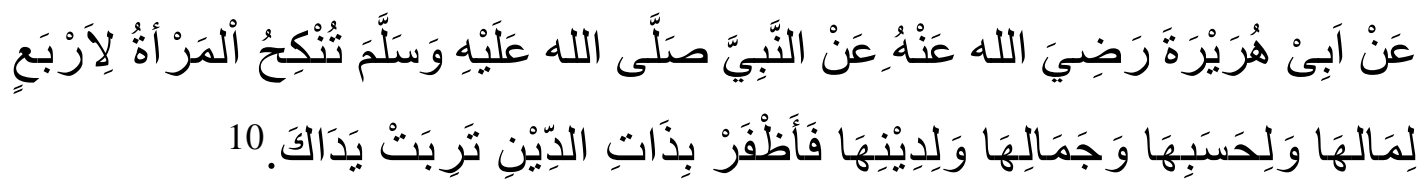

Artinya :

Dari Abu Hurairah ra, dari Nabi Saw bersabda: wanita itu dinikahi karena empat hal; karena hartanya, keturunannya, kecantikannya, dan agamanya. Pilihlah wanita yang mempunyai agama, niscaya kamu akan beruntung (HR. Bukhari).

\section{Proses khitbah}

Proses khitbah yakni melamar atau meminang, yaitu pernyataan permintaan perjodohan dari seorang pria kepada seorang wanita, atau sebaliknya, secara langsung maupun melalui perantara, untuk maksud melangsungkan pernikahan. Meminang dibolehkan dengan syarat bahwa pria maupun wanita yang dipinang tersebut belum bersuami/beristri, si perempuan tidak dalam keadaan talak yang belum babis masa iddahnya, dan tidak sedang dalam pinangan orang lain. ${ }^{11}$

Meminang seseorang bisa dilakukan secara adat setempat, seperti tukar cincin, asal-kan tidak bertentangan dengan tuntunan agama Islam. Proses ini biasanya disebut sebagai tunangan. Setelah pinangan tersebut dilakukan, hubungan kedua belah pihak keluarga semakin akrab. Namun, perlu diingat bahwa meskipun telah dipinang, bukanlah berarti telah dihalalkan bagi kedua pasangan tersebut untuk melakukan hubungan seksual atau hidup serumah layaknya pasangan suami-istri.

Selama belum dilangsungkan akad nikah atau ikatan perkawinan, selama itu

\footnotetext{
${ }^{10}$ Muhammad bin Isma'il bin Ibrahim bin al Mughirah bin Bardizbah, Shahih Bukhari (Beirut: Dar al-Fikri, t.t.), h. 103.

${ }^{11}$ Ibrahim Amini, Memlih Jodoh dan tatacara Meminang dalam Islam (Cet. III; Jakarta: Gema Insani Press, 1998), h. 83.
} 
pula hubugan seksual kedua pasangan belum dihalalkan, dan bilamana dilakukan hubungan seks juga, maka hal itu termasuk perilaku perzinaan, meskipun mereka melakukannya atas dasar suka sam suka dan telah mendapat restu dari keluarga. Selain itu, pinangan bisa putus sewaktu-waktu tanpa diawali dengan ucapan talak atau kata perceraian. Bilamana hal itu terjadi, pihak ketiga yang berniat untuk meminang orang yang telah putus hubungan tersebut, tidak perlu menunggu mesa iddah si perempuan. Bila proses khitbah atau melamar itu telah dilakukan, dalam jangka waktu yang tidak terlalu lama sebaiknya diteruskan dengan proses pernikahan. Karena, pasangan sudah dikenal melalui proses ta'aruf, dan direstui oleh keluarga melalui proses khitbah.

\section{Proses Pernikahan}

Tahap inilah yang menentukan apakah seseorang telah sah sebagai suami istri. Setelah dilangsungkan pernikahan, hubungan seksual antara keduanya yang semula diharamkan dan berdosa, menjadi bukan saja dihalalkan melainkan dihitung pahala. Proses nikah ini pula yang membedakan bentuk perkawinan makhluk selain manusia, seperti tumbuhan dan bina-tang. orang yang menikah dengan tujuan untuk menghindari atau mengantisipasi terjerumus dalam melakukan yang diharamkan akan mendapat pertolongan dari Allah swt.

Dengan demikian, pernikahan merupakan salah satu bentuk kehidupan manusia yang beradab. Hubungan seks tanpa nikah tak ubahnya seperti tumbuhan, binatang yang tak memiliki akal dan budaya. Dalam pemikahan, terdapat beberapa perkara yang tak boleh ditinggalkan, yakni adanya mempelai pria dan wanita, adanya seorang wali dari pihak perempuan, melakukan ijabqabul atau serah terima, disaksikan 
sedikitnya dua orang saksi lelaki, dan pemberian mahar atau maskawin dari pihak lelaki kepada mempelai perempuan. Tidak semua pria atau wanita boleh dinikahi. Diantara mereka ada yang diharamkan untuk dinikahi. Pada dasarnya ada dua kategori wanita yang haram dinkahi : pertama, haram dinikahi selama-lamanya, dan kedua, yang bersifat sementara saja karena adanya sebab yang menghalangi pemikahan tersebut, Bilamana sebab tadi sudahhilang, maka hukumnya berubah men-jadi halal.

Dewasa ini, telah muncul berbagai problema yang sebelum-nya tidak ada, dan bisa meru-pakan pengaruh modernisasi. Misalnya, akad nikah via telepon, maskawin terlalu tinggi (mahal), serta pernikahan di hotel berbintang yang bisa menelan biaya ratusan juta rupiah, atau upacara resepsi pernikahan yang dilangsungkan secara adat yang kadang kala diimbuhi dengan unsur mitos, sesajen serta simbol-simbol tertentu.

Akibat kemajuan teknologi komunikasi, seseorang yang berada di luar negeri bisa berbicara langsung dengan orang lain sekaligus melihat wajahnya lewat monitor secara online. Problema yang muncul adalah, bagaimana bila akad nikah dua calon mempelai dilangsungkan via telepon, yang jarak antara kedua belah pihak saling berjauhan. Dalam kitab-kitab fikih memang hal ini belum diungkap secara ekspilisit, namun bila dikembalikan kepada magashid al-syari'ah atau maksud hukum Islam yang sebenarnya adalah mempermudah prores pernikahan, bukan mempersulitnya. Akad nikah via telepon tersebut bisa menjadi alternatif dengan pertimbangan tertentu, misalnya adanya kekuatiran bahwa tanpa dilangsungkannya akad nikah segera pada waktu itu juga, akan menimbulkan fitnah atau perpecahan di antara dua keluarga, atau kondisi orang tua yang sakit parah dan menginginkannya mendapatkan kepastian 
calon suami atau istrinya.

Masalah maskawin mahal merupakan gejala yang muncul akhir-akhir ini, terutama di kalangan celebritis yang hidup mewah dan terkesan menghamburhamburkan harta kekayaan. Memang, Islam mensyaratkan adanya mahar kepada istri, tetapi mas kawin (mahar) mahal bukanlah tuntunan Islam. Sebab, hal itu bisa memberatkan pasangan yang hendak melangsungkan pernikahan. Hadis riwayat Tirmizi memberitakan bahwa Nabi saw bersabda:

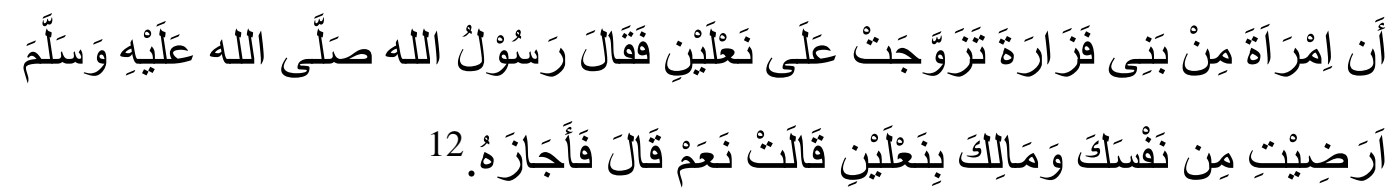

Artinya :

Sesungguhnya seorang dari Bani Farazah telah kawin dengan mahar sepasang sandal, bersabda Rasulullah saw.,: Apakah engkau relakan dirimu dan milikmu dengan sepasang sandal ? Jawab wanita itu: Ya, lalu Nabi membolehkannya.

Murahnya maskawin bukanlah menandakan murahnya harga jual si wanita sebab akad nikah tidaklah sama dengan akad jual-beli, dan maskawin bukanlah alat tukar atau alat bayar. Mas kawin adalah simbol sekaligus wujud pertanggungjawaban suami kepada istri. Murahnya maskawin bagi si istri merupakan bukti baiknya akhlak wanita tersebut. Wanita yang menuntut mas kawin terlalu mahal menandakan istri adalah seorang materialis, dan dengan demikian bukanlah wanita yang berakhlak mulia. Lagi pula, tujuan pernikahan itu bukanlah untuk menumpuk kekayaan, melainkan membina keluarga bahagia lahir-batin, jasmani-rohani dan dunia dan akhirat. ${ }^{19}$

Mahalnya maskawin bisa mencegah kalangan tak mampu untuk hidup

${ }^{12}$ Muhammad bin Isa bin Saurah bin Musa bin adl Dlahhak, Jami'u at Tirmidzi, (Beirut: Dar alFikri, t.t.), h. 202. 
membujang, atau terjerumus pada perzinhan. Dapat disaksikan kasus-kasus kaum dhu'afa yang tinggal di daerah kumuh. Mereka tidak memiliki pekerjaan yang tetap atau penghasilan yang cukup. Hal ini mengakibatkan sebagian di antara mereka memilih berpasangan tanpa ikatan nikah secara resmi. Begitu pihak Kementerian Agama setempat melaksanakan nikah massal, barulah tampak betapa banyak pasangan yang hidup serumah tanpa nikah tersebut, bahkan sebagiannya sudah beranak, atau usia lanjut. Umumnya mereka menempuh jalan demikian karena alasan ekonomi, selain mungkin karena kurangnya penghayatan terhadap agama.

Dalam melangsungkan pernikahan, diperlukan dua orang saksi laki-laki. Persaksian ini bisa diperluas dengan menyelenggarakan acara resepsi atau pesta pernikahan dengan mengundang para sahabat, handai tolan, kerabat, tetangga, serta kenala lainnya, agar dapat menyaksikan sekaligus memberi doa restu kepada kedua mem-pelai. Secara sosio-kultural pesta pemikahan (walimatul 'ursy) ini penting dilakukan agar pasangan tersebut dikenal dan mendapat pengakuan dari masyarakat. Sebaliknya, pernikahan yang di-lakukan secara sembunyi-sembunyi akan menimbulkan kecurigaan dan prasangka tidak baik dari warga sekitar. Meskipun demikian, dianjurkan pesta pernikahan itu hendaknya jangan dijadikan sebagai ajang pamer kekayaan dengan menghambur-hamburkan uang atau biaya tinggi, dan pesta mewah yang dilangsungkan di hotel berbintang yang dihadiri oleh tamu khusus kelas elit, sementara disekitarnya masih banyak dijumpai orang-orang fakir dan miskin.

\section{Proses Pembinaan Keluarga Sakinah}

Dalam al-Qur'an pernikahan itu adalah mitsaqan ghaliza artinya suatu ikatan/perjanjian yang kuat. Firman Allah Swt. : 


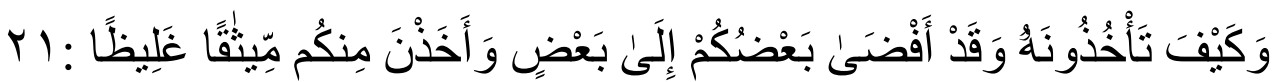

Terjemahnya :

Bagaimana kamu akan mengambilnya kembali, padahal sebagian kamu Telah bergaul (bercampur) dengan yang lain sebagai suami-isteri. dan mereka (isteri-isterimu) Telah mengambil dari kamu perjanjian yang kuat (QS. 4/An Nisa: 21). ${ }^{13}$

Nikah itu adalah suatu yang sakral dan merupakan sunah Rasulullah saw. Sebagamana Sabda Rasulullah Saw:

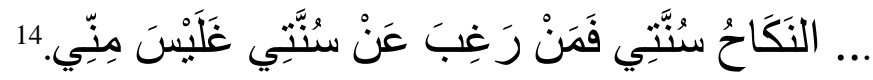

\section{Artinya :}

Nikah itu adalah sunnahku, maka siapa yang benci sunnahku maka sesungguhnya ia bukan dari golonganku" (H.R. Bukhari).

Adapun cara menjaga agar pernikahan itu langgeng, berikut beberapa solusi yang diberikan agama Islam :

a). Memperkokoh rasa cinta kita dan saling menjaga kehormatan

Cinta suami istrinya hendaknya senantiasa di perbaharui, jika perlu tiap hari diberi nafkah batin, sebab bila cinta mulai pudar, suami dapat saja melirik kesana kemari. Firman Allah Swt. :

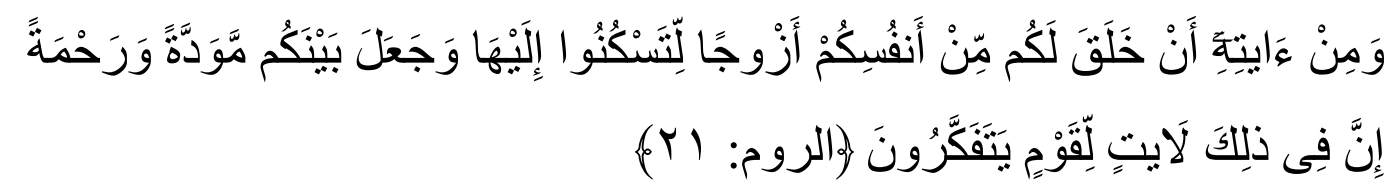

Terjemahnya :

\footnotetext{
${ }^{13}$ Kementerian Agama RI, Al-Qur'an dan Terjemahnya, h. 105.

${ }^{14}$ Muhammad bin Isma'il bin Ibrahim bin al Mughirah bin Bardizbah, Shahih Bukhari, h. 104.
} 
Dan di antara tanda-tanda ke-kuasaan-Nya ialah dia mencip-takan untukmu isteri-isteri dari jenismu sendiri, supaya kamu cenderung dan merasa tente-ram kepadanya, dan dijadi-kanNya diantaramu rasa kasih dan sayang... (QS. 30/Ar-Rum: 21). ${ }^{15}$

Baik suami maupun istri harus senantiasa menjaga kehormatan/harga diri. Seorang istri sebaiknya bila dipandang menyenangkan suaminya. Semua dilakukan dengan niat iklas. Oleh karena itu berusahalah menghidupkan cinta dalam rumah tangga.

\section{b). Saling Menghormati dan Menghargai}

Pasangan suami dalam men-jalani kehidupan rumah tangga saling menghargai dan menghormati satu sama lain merupakan hal perlu senantiasa dijaga. Allah Swt. berfirman

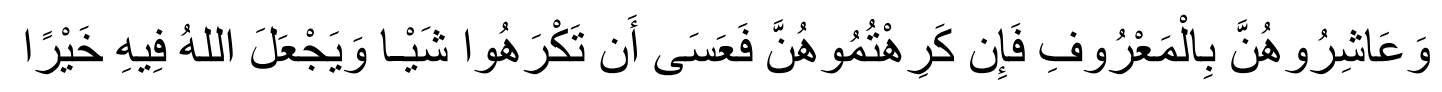

19: كَثْيرً

Terjemahnya :

bergaullah dengan mereka (istri-istrimu) dengan cara yang patut/baik. Kemudian bila kamu tidak menyukai mereka, maka bersabarlah karena mungkin kamu tidak menyukai sesuatu, padahal Allah men-jadikan padanya kebaikan yang banyak" (QS. 4/An Nisa: 19$){ }^{16}$

Artinya disini ada respect (penghargaan) satu sama lain. Setiap manusia sangat merasa suka bila dirinya dihargai dan dihormati. Itulah makanya banyak sekali keutuhan rumah tangga memudar dikarenakan tidak adanya penghargaan ataupun penghormatan terhadap pasangannya. Ada kejadian seorang suami yang berpenghasilan tinggi tidak menghargai istrinya yang tidak bekerja, dia beranggapan bahwa bila istrinya tidak keluar

\footnotetext{
${ }^{15}$ Kementerian Agama RI, Al-Qur'an dan Terjemahnya, h. 572.

${ }^{16}$ Kementerian Agama RI, Al-Qur'an dan Terjemahnya, h. 104.
} 
rumah untuk bekerja dianggap bukan bekerja, padahal perkerjaan rumah tangga yang dilakukan istrinya bukanlah pekerjaan yang mudah.

Oleh karena itu sebaiknya seorang suami senantiasa memuji istrinya yang telah bekerja di rumah, demikian pula istri harus senantiasa memuji suaminya yang bekerja di luar rumah. Ucapan terima kasih konon banyak memberi pengaruh terhadap diri kita, ada sense of respect. Kita banyak lihat di Australi, orang australia sering kali mengucapkan excuse me, thank you, ini juga merupakan bentuk respect atau penghargaan terhadap orang lain.

\section{c). Jangan Menyebarkan Kekurangan Pasangan Kita Masing-masing}

Istrimu adalah pakaian bagimu, demikian pula suamimu adalah pakaian bagimu. Oleh karena itu jangan sampai kekurangan yang ada pada pasangan kita sampai keluar dari rumah. Sebagaimana yang di jelaskan Allah SWT dalam QS. Al-Baqarah: 187 :

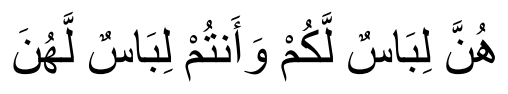

Terjemahnya :

mereka adalah Pakaian bagimu, dan kamupun adalah Pakaian bagi mereka ... (QS. 2/Al-Baqarah: 187). ${ }^{17}$

Ayat ini menerangkan bahwa menjelekkan pasangan kita sama saja dengan mengotori pakaian kita sendiri (men-jelekkan dirimu sendiri). Bila ada masalah sebaiknya diselesaikan dengan cara yang dingin, bahkan dapat pula dise-lesaikan ditempat tidur. d). Harus ada kerjasama (ta'awun) antara suami istri

\footnotetext{
${ }^{17}$ Kementerian Agama RI, Al-Qur'an dan Terjemahnya, h. 36.
} 
Ada anggapan bahwa pekerjaan rumah dan mendidik anak tanggungjawab ibu/istri, padahal sebenarnya pekerjaan dan mendidik anak tersebut adalah tugas bersama pasangan suami-istri. Firman Allah Swt. : dalam QS. Al-Maidah: 2:

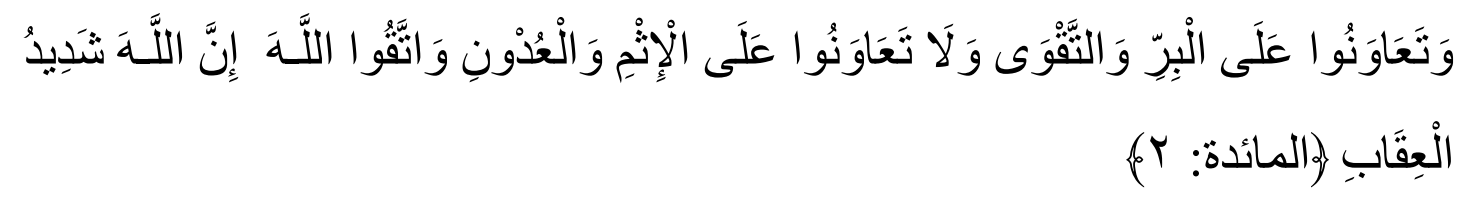

Terjemahnya :

Dan tolong menolonglah kamu dalam (mengerjakan) kebajikan dan takwa, dan jangan tolong-menolong dalam berbuat dosa dan pelanggaran. dan bertakwalah kamu kepada Allah, Sesungguhnya Allah amat berat siksa-Nya (QS. 3/Al-Maidah: 2). ${ }^{18}$

Ada kecenderungan anak lebih mendengar ibunya, atau orangtuanya ketimbang gurunya atau psikiater, oleh karena perlu adanya komunikasi yang baik antara orangtua dan anak. Jangan sampai kesibukan bekerja diluar, mebuat orangtua tidak sempat lagi memperhatikan dan berkomunikasi dengan anak. Sesibuk apapun, bila ada sedikit waktu manfaatkan waktu yang sedikit itu untuk berkomunikasi lebih baik dengan anak, sehingga hubungan orang tua dan anak menjadi baik. Dari hubungan baik itu ada semacam ikatan batin ataupun ikatan emosional antara anak dengan orang tua. Hal ini penting sekali terutama memenangkan atau menundukkan hati anak kita, sebab bila anak kita sudah tunduk, maka mudahkan kita ajarkan, agama, moral dsb.

e). Memfungsikan keluarga kita dengan optimal guna membentuk manusia paripurna, muttaqin.

Adalah penting bagi orang tua mengajarkan anaknya pendidikan agama sejak dini. Anak merupakan amanah Allah kepada orangtuanya. Dari Abu Hurairah, Rasulullah saw.

\footnotetext{
${ }^{18}$ Kementerian Agama RI, Al-Qur'an dan Terjemahnya, h. 141.
} 
Ber-sabda: "Setiap anak dilahirkan dalam keadaan fitrah (suci yakni Muslim). Kedua orangtuanyalah yang menjadikan dia Yahudi, Nasrani atau Majusi."(Bukhari). ${ }^{19}$

Pendidikan agama Islam sejak dini sangat penting terutama didalam membentuk karakter anak. Ketika ada kesa-lahan pada anak, segera tegur, namun tegurlah dengan cara yang baik, tidak dengan kekerasan. Sebab bila kita mendidik dengan kekerasan maka generasi yang terbentuk akan keras juga.

Ajarkan anak untuk menjadi manusia yang muttaqin yaitu senantiasa menjalankan perintah-Nya dan menjauhi larangan-Nya. Suami juga harus mendidik istrinya, menjadi istri yang baik. Bila istri ada kesalahan maka tergurlah, bila tidak didengar setelah ditegur sekali, dua kali, tiga kali, maka berpisah ranjanglah, bila tidak mempan juga maka pukullah (pukul disini maksudnya ditegur dengan keras). Jadi mendidik keluarga disini sangatlah penting dalam rangka membentuk manusia yang paripurna (muttaqin).

\section{Implementasi Cinta dan Kasih Sayang Menurut Hukum Islam}

Ajaran cinta dan kasih sayang dalam ajaran Islam sangat ideal sekiranya dapat diimplementasikan dalam pola sikap dan perilaku sehari-hari dalam masyarakat di manapun. Cinta kepada Allah hendaklah menjiwai cinta kepada yang lain. ${ }^{20}$ Hanya dengan rasa cinta dan ka sih sayang yang tulus yang dijiwai oleh iman kepada Allah,

${ }^{19}$ Athian Ali Moh. Dan'i, Keluarga Sakinah (Cet.III; Jakarta: PT. Raja Grafmdo Persada, 2004), h. 260 .

\footnotetext{
${ }^{20}$ Menurut Hasbi ada 8 cinta manusia yang alami (mahabbah tabî‘iyyah) yaitu: 1) cinta kepada ayah ibu atau cinta anak kepada ibu-bapaknya; 2) cinta orangtua terhadap anak-anaknya; 3) cinta saudara terhadap saudaranya yang lain; 4) cinta teman hidup atau suami terhadap istrinya dan sebaliknya; 5) cinta antar kaum famili atau kerabatnya; 6) cinta perniagaan yang dikhawatirkan akan kerugiannya; 7) cinta tempat tinggal atau kediamannya; dan 8) cinta harta atau kekayaan. M. Hasbi Ash-Shiddieqy, Al-Islam, (Jakarta; Bulan Bintang, 1964), jilid I, h. 158
} 
berbagai benturan dalam masyarakat dapat dicegah dan dikurangi, karena pada dasarnya sumber segala keburukan adalah rasa benci yang dibiarkan alam diri manusia.

Dalam kehidupan sehari-hari, manusia umumnya tidak lepas dari tiga lembaga kemasyarakatan yang utama, yaitu keluarga, sekolah, dan masyarakat. Dalam kaitan dengan itu, uraian berikut akan menjelaskan bagaimana mengimplementasikan ajaran cinta dan kasih sayang yang diajarkan dalam Al-Qurean melalui tiga kelembagaan utama itu.

\section{Keluarga}

Keluarga, yang dalam bahasa Arab disebut usrah atau 'â'ilah dan dalam bahasa Inggris disebut family, merupakan unit terkecil dalam suatu masyarakat. Suatu keluarga biasanya terdiri dari suami, istri, dan anak. Dalam ajaran Islam pembentukan suatu keluarga dilakukan melalui pernikahan. Tata cara pernikahan ini dibahas dalam kitab Munakahah. Nikah merupakan perintah Allah dan sunah Nabi. Perintah nikah dapat dilihat dalam Q.S. 4/al-Nisâ' : 3:

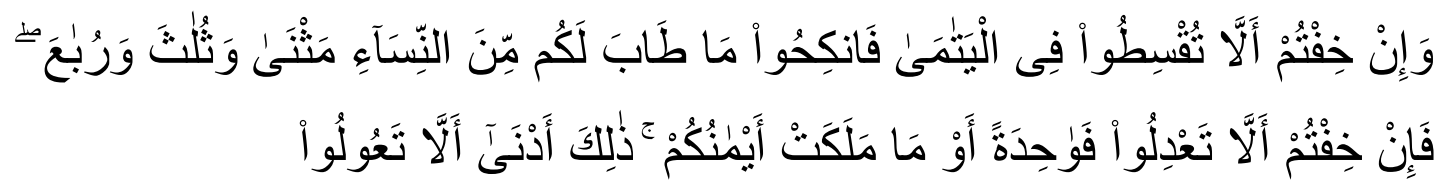

Terjemahnya :

Dan jika kamu takut tidak akan dapat berlaku adil terhadap (hak-hak) perempuan yang yatim (bilamana kamu mengawininya), maka kawinilah wanita-wanita (lain) yang kamu senangi: dua, tiga atau empat. Kemudian jika kamu takut tidak akan dapat berlaku adil, maka (kawinilah) seorang saja, atau budak-budak yang kamu miliki. Yang demikian itu adalah lebih dekat kepada tidak berbuat aniaya.

(QS. Al-Maidah: 3). 
Hingga kini, keluarga masih merupakan tempat atau lembaga pendidikan anakanak, terutama pendidikan moral dan agama. Ayah dan ibu merupakan pendidik pertama dan utama dalam setiap keluarga. Oleh karena itu, dalam proses pemilihan pasangan (mate) hendaklah didasari rasa cinta (mahabbah mawaddah/love) satu sama lain. Beth B. Hess dalam Sociology mengupas tentang cinta dalam kaitannya dengan pemilihan pasangan (mate selection). Ia menyebutkan adanya "romantic love syndrome " yang muncul sebagai suatu dasar atau alasan yang baru dalam memilih suami atau istri ( a new basis for choosing a husband or a wife). Tegasnya istilah di atas digunakan bagi setiap orang yang hanya menekankan cinta sebagai satu-satunya alasan dalam memilih pasangan hidup (focuses on love as the sole reason for choosing a mate). ${ }^{21}$

Dalam kaitannya dengan cinta ini Allah berfirman dalam Q.S. 30/al-Rûm : 21:

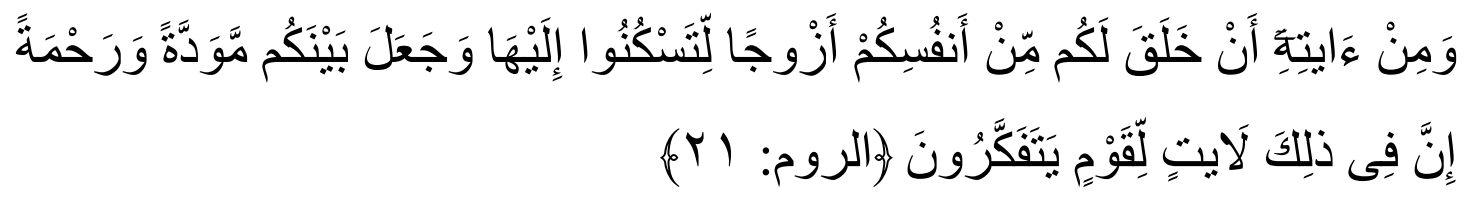

Terjemahnya :

Dan di antara tanda-tanda ke-kuasaan-Nya ialah dia mencip-takan untukmu isteri-isteri dari jenismu sendiri, supaya kamu cenderung dan merasa tente-ram kepadanya, dan dijadi-kanNya diantaramu rasa kasih dan sayang. Sesungguhnya pada yang demikian itu benar-benar terdapat tanda-tanda bagi kaum yang berfikir (QS. 30/Ar-Rum: 21)

Dari ayat di atas dijelaskan bahwa hidup berkeluarga merupakan dorongan fitri manusiawi yang berasal dari Allah dan perlu penyaluran secara sehat. Dengan penyalura berbagai dorongan seperti seks, berkomunikasi, bertanggung jawab, mempertahankan

\footnotetext{
${ }^{21}$ Beth B. Hess et. al., Sociology , (New York: Macmillan Publishing Company, 1985), 2nd Ed.,
} h. 263 
keturunan, mencintai dan dicintai, dan sebagainya, maka jiwa menjadi tenang dan tenteram. Dari ayat di atas diperoleh petunjuk bahwa cinta dan kasih sayang (mawaddah wa rahmah) dapat saja datang setelah terjadi pernikahan. Dalam ajaran Islam masalah keluarga diatur berdasar Al-Qur'an dan sunah Nabi dan di Indonesia tertuang dalam UU Perkawinan No. 1 Tahun 1974. Walaupun sumber ajarannya sama yaitu Al-Qur'an dan sunah, namun terjadi perbedaan para mujtahid dalam menentukan syarat, rukun dan lain-lain dalam pernikahan.

Perbedaan pendapat ulama itulah yang kemudian menimbulkan beberapa mazhab dalam fikih di antaranya yang terkenal ialah Hanafiah, Malikiah, Syafiiah, dan Hanabilah. Dalam hal merawat cinta kasih suami istri ini, Ibrahim Amini dalam rinciple of Marriage Ethics menjelaskan perlunya seorang istri mengungkapkan rasa cintanya kepada suami. Hal ini perlu karena setiap orang ingin dicintai dan disayangi, lebih-lebih seorang suami dari istrinya. Orang yang tidak mendapat rasa cinta dan kasih sayang dari orang lain akan merasa sepi dan terasing. Sebaliknya seorang suami yang merasa dicintai dan disayangi oleh istrinya ia akan merasa bangga dan bersemangat dalam hidup dan bekerja, perasaan mejadi lega dan puas. ${ }^{22}$

Rasa cinta tidak cukup disimpan dalam hati, tetapi perlu diungkapkan dengan sikap dan perilaku. Jika cinta hanya disimpan dalam hati, suami tidak tahu kalau istrinya cinta. Walaupun begitu, menurut Erich Fromm tidak baik jika seseoramg hanya akan

\footnotetext{
${ }^{22}$ Ibrahim Amini, Principle of Marriage Ethics, (Jakarta:1984). h. 22, 131, Cf. Hernowo, M. Deden Ridwan (Ed.), Aa Gym dan Fenomena Rdarut Tauhid, Memeprbaiki Diri lewat mnajemen Qalbu, (Bandung: Mizan, 1423/2002), cet. Ke-4, h. 210.
} 
menuntut untuk dicintai, tetapi sebaliknya hendaklah masing-masing berusaha untuk memberikan cintanya kepada pihak lain dengan tulus. ${ }^{23}$

Jika orang menekankan untuk dicintai hampir selalu akan mengalami kekecewaan. Sebab hampir tidak ada seorangpun yang merasa telah memperoleh cinta yang sepenuhnya. Akhirnya berbagai perbedaan dari kedua pihak akan dinilai sebagai tidak atau kurang mencintai. Oleh karena itu perlu juga menjelaskan perlunya suami mengungkapkan cintanya kepada istri agar cinta itu terjadi timbal balik. Jika suami tidak mau menyatakan mencintai istrinya, maka mungkin istri akan mencari cinta dari orang lain atau berselingkuh.

Dalam kaitan ini Allah memperingatkan dalam Q.S. 17/al-Isrâ': 32:20

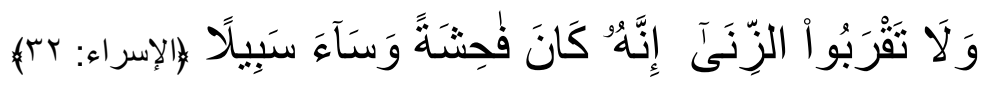

Terjemahnya :

Dan janganlah kamu mendekati zina; sesungguhnya zina itu adalah suatu perbuatan yang keji. Dan suatu jalan yang buruk. (QS. Al-Isra: 32)

Pengungkapan cinta memang tidak selalu harus dalam bentuk benda atau materi, tetapi yang lebih penting adalah dalam bentuk sikap dan perilaku. Misalnya muka yang manis, perilaku yang sopan, sekali-sekali bersendau-gurau, pergi bersama dan sebagainya. Suami istri yang sudah berlangsung lama biasanya dihinggapi penyakit kejenuhan. Untuk itu diperlukan kedua belah pihak aktif dan kreatif mencari cara-cara menghilangkan atau mengurangi kejenuhan dan suasana menjadi segar. Suami istri yang sering bertengkar atau jarang pergi bersama berarti alamat rasa cinta dari kedua belah pihak mulai berkurang, lama kelamaan akan hilang dan berubah menjadi kebencian. ${ }^{24}$

\footnotetext{
${ }^{23}$ Erich Fromm, op. cit., h. 2
}

${ }^{24}$ Menurut Quraish Shihab dalam rangka menjaga keutuhan rumah-tangga perlu diperhatikan tali temali pengikat perkawinan yaitu cinta, mawaddah, rahmah dan amânah. Dikatan bahwa cinta ada masa kelahirannya dan ada saat perkembangannya, baik menurun maupun menanjak, dan bisa juga ada masa kematiannya. Di atas cinta ada yang seharusnya mengikat suami istri yaitu mawaddah dan rahmah. Mawaddah dinilai sebagai cinta plus yaitu kelapangan dada dan kekosongan jiwa dari kehendak buruk. 
Adapun yang sulit dalam suatu keluarga ialah merawat dan menjaga kelangsungan cinta serta bagaimana menjaga keseimbangan antara upaya untuk mencintai dengan tuntutan untuk dicintai. Kerap kali seseorang hanya selalu menuntut untuk dicintai yang tidak jelas ukurannya sementara ia sendiri lupa telah sejauhmana memberikan cintanya kepada pihak lain.

Dalam menjaga keharmonisan suami-istri, merawat cinta-kasih, sangat tergantung kematangan emosi dan pikiran kedua belah pihak yang biasanya paralel dengan bertambahnya usia dan pengalaman. Yang tidak kalah pentingnya dalam hubungan suami sitri ialah masih banyaknya anggapan bahwa istri harus taat dan patuh sepenuhnya kepada suami dan kurang dipandang sebagai mitra sejajar. Hal itu sebagai akibat budaya paternalistik yang masih berlaku di mana-mana. Karena itu banyak suami yang selalu ingin menang sendiri dan berlaku sewenang-

wenang.

Sementara itu, hubungan orangtua dengan anak juga sangat penting agar anak tumbuh dan berkembang sehat jasmani dan rohani, tertanam rasa cinta kepada ibu bapak serta kakak adik. Anak harus selalu diajak berdialog secara terbuka tanpa ada rasa takut. Sebenarnya setiap pasangan suami istri idealnya telah dibekali pengetahuan atau ilmu bagaimana cara menghadapi anak dengan baik. Apa saja yang diperlukan bagi partumbuhan jasmani agar sehat.

Dengan mengutip Ibarahim al-Biqa'y dikatakan bahwa mawaddah adalah "cinta yang tampak dampaknya pada perlakuan." Sementara " rahmah menghasilkan kesabaran, murah hati, tidak cemburu, pemiliknya tidak angkuh, tidak mencari keuntungan sendiri, tidak juga pemarah apalagi pendendam.” Lihat M. Quraish Shihab, Untaian Permata Buat Anakku (Pesan Al-Qur'an untuk Mempelai), (Jakarta: Al-Bayan, $1421 / 2001$ ), cet. ke-8, h. 40 
Adapun yang lebih penting lagi ialah pengetahuan bagaimana memperlakukan anak agar rohaninya berkembang dengan sehat. Karena cinta Nabi kepada putrinya ia menggelari Fatimah dengan ummu abihâ, ibu yang merawat ayahnya, sebagai sanjungan atas perhatiannya kepada ayah. Dengan Hasan dan Husain, Nabi juga sangat sayang dan biasa digendong dan diciumnya.

\section{Dalam Sekolah}

Sampai sekarang masyarakat masih beranggapan bahwa sekolah tetap merupakan lembaga pendidikan yang penting. Dalam Islam ilmu sangat dijunjung tinggi. Bahkan ayat-ayat pertama yang turun berkenaan dengan membaca dan penulis sebagaimana firman Allah dalam Q.S. 96/al-`Alaq:1-6.

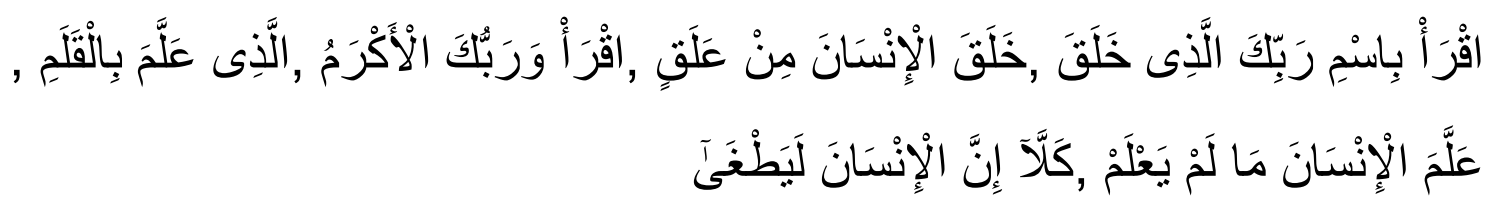

Terjemahan :

1) Bacalah dengan (menyebut) nama Tuhanmu Yang menciptakan, 2) Dia telah menciptakan manusia dari segumpal darah, 3) Bacalah, dan Tuhanmulah Yang Maha Pemurah, 4) Yang mengajar (manusia) dengan perantaran kalam, 5) Dia mengajar kepada manusia apa yang tidak diketahuinya, 6) Ketahuilah! Sesungguhnya manusia benar-benar melampaui batas.

Ayat di atas secara tegas menekankan perlunya umat Islam mencintai ilmu dengan gemar membaca dan menulis sejak dini. Hampir tidak ada seorangpun yang menganggap bahwa anaknya tidak perlu bersekolah, tetapi cukup dididik oleh orang tuanya sendiri di rumah. Menanamkan nilai-nilai cinta di sekolah atau madrasah memerlukan peran guru yang sangat besar di samping kurikulumnya. Keharmonisan hubungan antar-guru akan sangat berpengaruh positif bagi anak didik. Sebaliknya 
permusuhan dan pertengkaran antarguru akan sangat berpengaruh negatif bagi peserta didik.

Kejujuran, ketulusan, dan sikap sayang dan cinta guru kepada anak didik sangat menentukan sikap peserta didik. Menanamkan nilai-nilai cinta di sekolah dapat dilakukan melalui berbagai metode atau cara. Cinta guru kepada murid dapat dilakukan dengan cara menyadari tugas-tugas guru yang di samping sebagai pengajar juga sebagai pendidik. Akan tetapi, yang tidak kalah pentingnya ialah mencintai tugas dan kewajibanya sebagai guru dan pendidik, atau cinta kepada profesinya. Seseorang yang telah mencintai profesinya akan rela meluangkan waktunya demi peserta didiknya dan dalam menunaikan profesinya tidak terlalu memperhitungkan imbalan atau gaji yang diperolehnya. Sebagai pendidik harus dapat memberi contoh atau teladan yang baik, baik di dalam maupun di luar kelas. ${ }^{25}$

Sayangnya dewasa ini, akibat modernisasi dan berbagai kemajuan dalam berbagai bidang kehidupan, manusia menjadi kritis, egois, materialis dan kurang memperhatikan nilai-nilai moral dan agama. Adanya guru agama di sekolah hampir tidak ada bekasnya bagi para siswa karena lingkungan sekolah, masyarakat dan keluarga kurang mendukungnya. Ajaran Islam menyatakan bahwa kesehateraan sosial dimulai dari perjuangan mewujudkan dan menumbuh suburkan aspek-aspek akidah dan etika pada diri pribadi, karena dari diri pribadi yang seimbang akan lahir masyarakat yang seimbang. ${ }^{26}$

\section{Dalam Masyarakat}

Masyarakat tersusun dari banyak keluarga dan keluarga terdiri dari beberapa individu. Dalam suatu masyarakat biasanya terdapat bermacam-macam lembaga seperti

${ }^{25}$ Karel A. Steenbrink, Pesantren, Madrash, Sekolah , (Jakarta, LP3S, 1986), cet. ke-1. Cf. Zamakhsyari Dhofier, Tradisi Pesantren, (Jakarta: LP3ES, 1982), cet. ke-1.

26 Arsyam, M., \& Alwi, A. M. (2020, August 18). Konsep dan Makna Kesejahteraan dalam Pandangan Islam. https://doi.org/10.31219/osf.io/2yusv 
lembaga pendidikan, lembaga keagamaan, lembaga ekonomi, lembaga perkawinan dan lain-lain. Pada dasarnya, baiknya suatu masyarakat tergantung kepada baiknya keluargakeluarga dan baiknya suatu keluarga tergantung kepada baiknya individu-individu dalam keluarga, sedang baiknya individu tergantung kepada pembawaan dan lingkungan yang baik. (Kementerian Agama RI) dalam Al-Qur'an Surah Al-An'am ayat 38 Islam sebagai agama yang lengkap (kaffah) yang ajarannya meliputi berbagai aspek. ${ }^{27}$ Akan tetapi, masalah masyarakat manusia tidak seperti masyarakat binatang atau tumbuh-tumbuhan atau benda mati yang mudah ditebak sebab musababnya. Masyarakat manusia amat banyak faktornya dan sulit menebak sebab dan akibatnya. Ukuran baik buruk memang sering terdapat perbedaan antara yang satu dengan yang lain. Salah satu contoh dalam kehidupan adalah seperti dalam suatu hadits, Rasulullah SAW menganjurkan agar para pedagang selalu bermurah hati dalam melaksanakan jual beli. Murah hati dalam pengertian; ramah tamah, sopan santun, murah senyum, suka mengalah, namun tetap penuh tanggungjawab. ${ }^{28}$ Sehingga akan terjaling rasa cinta diantara kita sesama para pedagang.

Pada masa Nabi, masyarakat Arab sudah beragama, ada yang menganut Yahudi, Nasrani, dan Islam. Dalam upaya meredakan ketegangan masyarakat dibuatlah kesepakatan dalam bentuk piagam yang dikenal Piagam Madinah. ${ }^{29}$ Dalam Islam, AlQurean selain berisi hukum Ilahi juga syarat dengan nilai-nilai moral seperti takwa, sabar, dermawan, adil dan sebagainya dan didukung dengan ketulusan ibadah, semata-

27 Jumliadi, J., Zakirah, Z., Arsyam, M., Alwi, A. M. S., \& Fadhil, M. PEMBELAJARAN DIRUMAH DALAM LINGKUNGAN KELUARGA DI TENGAH PANDEMI COVID 19.

${ }^{28}$ Ahmad, H., \& Arsyam, M. (2020, September 12). ETIKA PERDAGANGAN DALAM ISLAM. https://doi.org/10.31219/osf.io/u45gn

${ }^{29}$ Ahmad Baso, Civil Society versus Masyarakat Madani, (Bandung: Pustaka Hidayah, 1420/1990), cet. ke-1, h. 331-351. 
mata mengharap kerelaan dan cinta Allah.

Sarwono Ahmad (Abu Aqilah al-Sawiti) secara rinci menulis Pesona Akhlak Rasûlullâh saw. Dalam buku tersebut diuraikan bagaimana Nabi menghadapi istri, para sahabat, anak kecil, kaum papa (duafâ'), binatang, bahkan musuh-musuhnya. Memang bagi umat Islam tak ada jalan lain kecuali berteladan kepada Rasul (uswah hasanah) yang akhlaknya merupakan ekspresi nilai-nilai Al-Qurean. ${ }^{30}$ Karena itulah Nabi diutus untuk menyempurnakan akhlak, yang dinyatakan dalam sabdanya: "Innamâ bu'iśtuli'utammima makârim al-akhlâq) dan sebagai anugerah alam semesta (Q.S. 21/ al-Anbiyâ'. 107:

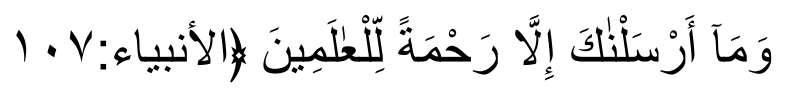

Terjemahan :

Dan tiadalah Kami mengutus kamu, melainkan untuk (menjadi) rahmat bagi semesta alam. (Q.S. al-Anbiyâ'. 107)

Bertetangga yang ideal, sebagai bagian dari pola sikap bermasyarakat berdasar sunnah Nabi Muhammad saw., yang oleh Abdurrahman Maseeud disebut sebagai "humanisme religius".

${ }^{30}$ Abu Aqilah al-Sawiti, Pesona Akhlak Rasulullah saw., (Yogyakarta: UI Press, 2004), cet. ke-2, h. 15 


\section{BAB III}

\section{KESIMPULAN}

Hakekat cinta dalam Hukum Islam mengandung makna yang luas dan rinci, dalam arti mencakup berbagai segi. Cinta merupakan perasaan senang dan bahagia terhadap sesuatu, sebagai anugerah Allah yang intensitasnya dapat meninggi atau merendah bahkan dapat hilang dan menjadi benci. Cinta ini memiliki nilai yang bertingkat-tingkat. Yang tertinggi ialah cinta kepada Allah, kemudian menyusul cinta kepada Rasul Allah, kemudian cinta kepada perjuangan di jalan Allah, baru kemudian cinta kepada yang lain.

Hukum Islam memiliki kiat dan aturan tersendiri dalam menyemai cinta dan membina keluarga. Aturan-aturan normatif hukum Islam berbeda dengan aturan dan budaya yang berlaku pada masa sekarang, terutama aturan dan budaya yang merupakan pengaruh gaya hidup modern dari Barat. Di samping itu, hukum Islam telah mengatur pergaulan laki-laki dan wanita pra dan pasca perkawinan. Pra perkawinan, laki-laki dan wanita tidak boleh mengarah kepada perzinahan. Pasca perkawinan suami-istri harus menjalankan kewajibannya, agar kedua pihak dapat memperoleh haknya masing-masing secara proporsional. Di samping itu, suami-istri harus cerdas memilih sikap, prilaku dan kata-kata yang dapat menyenangkan pasangannya, sehingga kebahagiaan (cinta) keluarga dapat langgeng.

Implementasi cinta dan kasih sayang menurut Hukum Islam dapat dirasakan dalam pola sikap dan prilaku sehari-hari, baik dalam kehidupan keluarga, sekolah, dan masyarakat. 


\section{DAFTAR PUSTAKA}

Al-Turmudzi, Abu 'Isa Muhammad bin 'Isa bin Surah Al-Turmudziy, al-Jami' al-Shahih, Juz. III ex-Beirut: Dar al-Kitab, t.th.

Abu Aqilah al-Sawiti, Pesona Akhlak Rasulullah saw., Yogyakarta: UI Press, 2004

Amini, Ibrahim. MemIlih Jodoh dan tatacara Meminang dalam Islam. Cet. III; Jakarta: Gema Insani Press, 1998.

Athiyyah Shaqr, Syeikh. Fatawa li al-Syabab, Diterjemah oleh M.Wahib Aziz dengan Judul Fatwa Kontemporer Seputar Dunia Remaja. Cet.I; Jakarta: Amzah, 2003.

Al-Bukhariy, Abdullah Muhammad Ibn Ismail. Shahih al-Bukhari Juz 4. Indonesia: Maktabah Dahlan, t.th.

Al-Gifari, Abu, Fiqih Remaja Kontemporer. Cet.I; Bandung: Media Qalbu, 2005.

Ahmad, H., \& Arsyam, M. (2020, September 12). ETIKA PERDAGANGAN DALAM ISLAM. https://doi.org/10.31219/osf.io/u45gn

Ahmad Baso, Civil Society versus Masyarakat Madani, (Bandung: Pustaka Hidayah, $1420 / 1990$

Arsyam, M., \& Alwi, A. M. (2020, August 18). Konsep dan Makna Kesejahteraan dalam Pandangan Islam. https://doi.org/10.31219/osf.io/2yusv

Arsyam, M., \& Kusnadi Umar, Z. Z. MANUSIA SEBAGAI PENDIDIK PERPEKTIF ISLAM DAN BARAT.

Athian Ali Moh. Dan'i, Keluarga Sakinah (Cet.III; Jakarta: PT. Raja Grafmdo Persada, 2004

Beth B. Hess et. al., Sociology, (New York: Macmillan Publishing Company, 1985

Departemen Agama R.I. Al Quran dan Terjemahnya, Bandung: CV Diponegoro, 2013

Hernowo, M. Deden Ridwan (Ed.), Aa Gym dan Fenomena Rdarut Tauhid, Memeprbaiki Diri lewat mnajemen Qalbu, Bandung: Mizan, 1423/2002

Ibrahim Amini, Principle of Marriage Ethics, Jakarta:1984 
Jumliadi, J., Zakirah, Z., Arsyam, M., Alwi, A. M. S., \& Fadhil, M. PEMBELAJARAN DIRUMAH DALAM LINGKUNGAN KELUARGA DI TENGAH PANDEMI COVID 19.

Kementerian Agama RI. Al-Qur'an dan Terjemahnya. Jakarta: Proyek Peningkatan Pelayanan Kehidupan Beragama Pusat Ditjen Bimas Islam, 2012.

Karel A. Steenbrink, Pesantren, Madrash, Sekolah, Jakarta, LP3S, 1986.

Kementerian Pendidikan Nasional. Kamus Besar Bahasa Indonesia (Jakarta: Balai Pustaka, 2002.

M. Hasbi Ash-Shiddieqy, Al-Islam, Jak 29 lan Bintang, 1964

Muslim, Abi Husain bin Hajjaj al-Qusyairiy an-Naisaburiy, Shahih Muslim Juz 3. Beirut: Dal al-Kitab al-Ilmiyah, 1992M-1413H.

M. Quraish Shihab, Untaian Permata Buat Anakku (Pesan Al-Qur'an untuk Mempelai), Jakarta: Al-Bayan, 1421/2001

Moh. Dan'i, Athian Ali. Keluarga Sakinah. Cet.III; Jakarta: PT. Raja Grafmdo Persada, 2004.

Muhammad Bin Yazid Abu Abdullah A1-Qazwaniy. Sunan Ibnu Majah, Juz. II. Beirut: Dar AI-Fitri, t.th.

Thohir, Muhammad. Pengantar Memasuki Paradigms Baru Kehidupan yang Lebih Bermartabat, Lebih Sehat den Lebih Bahagia. CetI; Jakarta: Lentera Hati, 2006.

Umar, Ali Hasan. Kejahatan seks dan Kehamilan di Luar Nikah dalam Pandangan Islam. cet. I; Semarag: Panca Agung, 2003.

Zamakhsyari Dhofier, Tradisi Pesantren, Jakarta: LP3ES, 1982 